\title{
Pulmonary hypertension in left heart disease
}

Pratishtha Mehra ${ }^{1}$, Vimal Mehta ${ }^{1}$, Rishi Sukhija ${ }^{2}$, Anjan K. Sinha ${ }^{3}$, Mohit Gupta $^{1}$, M.P. Girish ${ }^{1}$, Wilbert S. Aronow ${ }^{4}$

1Department of Cardiology, Maulana Azad Medical College and G.B. Pant Institute
of Postgraduate Medical Education and Research, New Delhi, India
2Division of Cardiology, Indiana University La Porte Hospital, La Porte, Indiana, USA
${ }^{3}$ Division of Cardiology, Indiana University Health, Indianapolis, Indiana, USA
${ }^{4}$ Division of Cardiology, New York Medical College, Valhalla, NY, USA

Submitted: 26 July 2016

Accepted: 14 September 2016

Arch Med Sci 2019; 15, 1: 262-273

DOI: https://doi.org/10.5114/aoms.2017.68938

Copyright (c) 2017 Termedia \& Banach

Pulmonary hypertension $(\mathrm{PH})$ is a severe, progressive disease which may be idiopathic or is associated with or is a sequela of underlying other disease. It is defined as elevation of mean pulmonary artery pressure (mPAP) of $\geq 25 \mathrm{~mm} \mathrm{Hg}$ at cardiac catheterization. A clinical classification characterizes disorders causing $\mathrm{PH}$ into five groups, based on similar pathological findings, hemodynamic characteristics, and management (Table I) [1]. Pulmonary hypertension associated with left heart disease (PH-LHD) is classified as group $2 \mathrm{PH}$ and represents the most prevalent form of $\mathrm{PH}$ [2].

Typically many patients with left heart disease develop $\mathrm{PH}$ as their primary cardiac disorder progresses. Hence the prevalence of $\mathrm{PH}$ increases in a particular left heart disease with advancing functional class (Table II) [3-8]. PH-LHD is common in patients with heart failure with preserved (HF-PEF) [4] or reduced ejection fraction (HF-REF) [9] and in valvular heart disease [5-8]. When present, $\mathrm{PH}-\mathrm{LHD}$ results in more severe symptoms and worse exercise tolerance [10-13]. In general the development of $\mathrm{PH}$ in a patient with left heart disease portends a poor prognosis vis-a-vis normal pulmonary artery pressures [14].

\section{Pre-capillary and post-capillary pulmonary hypertension}

If the underlying pathology is predominantly in the pulmonary arterioles and small pulmonary arteries, $\mathrm{PH}$ is termed pre-capillary. If the underlying cause of raised PAP is left heart disease, $\mathrm{PH}$ is termed isolated post-capillary PH (Ipc-PH). By definition, in Ipc-PH the raised PAP is a passive phenomenon meaning there is no intrinsic pathology in pulmonary circulation (at least in the beginning) so as to maintain forward flow in response to elevated left sided filling pressures. However in many patients chronic passive elevation of PAP leads to pathologic changes in the small pulmonary arteries and arterioles such that the process is no longer passive. The raised PAP in such cases has dual cause: elevated left sided filling pressures and intrinsic pulmonary vascular disease termed combined post-capillary and pre-capillary $\mathrm{PH}(\mathrm{Cpc}-\mathrm{PH})$.

\section{Hemodynamics}

Pulmonary hypertension is defined hemodynamically by invasive right heart catheterization (RHC) as $\mathrm{mPAP} \geq 25 \mathrm{~mm} \mathrm{Hg}$ and a normal or reduced cardiac output. The severity of $\mathrm{PH}$ is graded by Doppler
Corresponding author: Prof. Wilbert S. Aronow MD, FACC

Division of Cardiology New York Medical College Macy Pavilion, Room 141 Valhalla, NY10595 USA Phone: 914-493-5311 E-mail: wsaronow@aol.com 
echocardiography based on estimated peak PAP as mild $36-45 \mathrm{~mm} \mathrm{Hg}$, moderate $46-60 \mathrm{~mm} \mathrm{Hg}$ and severe if $>60 \mathrm{~mm} \mathrm{Hg}$. The RHC based grading is by mean PAP: mild $25-40 \mathrm{~mm} \mathrm{Hg}$, moderate 41-55 $\mathrm{mm} \mathrm{Hg}$ and severe $>55 \mathrm{~mm} \mathrm{Hg}$ [12, 15-17]. The main hemodynamic parameter that differentiates PH-LHD is pulmonary capillary wedge pressure (PCWP) measured at end-expiration. A PCWP cut-off of $15 \mathrm{~mm} \mathrm{Hg}$ defines whether $\mathrm{PH}$ is pre-capillary (PCWP $\leq 15 \mathrm{~mm} \mathrm{Hg}$ ) or post-capillary (PCWP > $15 \mathrm{~mm} \mathrm{Hg}$ ).

Transpulmonary gradient (TPG) and diastolic pulmonary gradient (DPG) differentiate whether $\mathrm{PH}$ is passive or reactive. The TPG is defined as difference between mean PAP and mean PCWP (TPG = $m P A P-m P C W P)$. A TPG $<12 \mathrm{~mm} \mathrm{Hg}$ defines passive $P H$ and $T P G \geq 12 \mathrm{~mm} \mathrm{Hg}$ defines reactive $P H$. Diastolic PAP is less influenced by increased PCWP than systolic PAP and mean PAP. Therefore, raised PCWP will result in marked increase in systolic PAP and mean PAP with no or little increase in diastolic PAP [13]. Diastolic pulmonary gradient defined as difference between diastolic pulmonary artery pressure (dPAP) and mean PCWP (DPG = dPAP $\mathrm{MPCWP}$ ) is a marker of pulmonary vascular disease. In normal subjects DPG is $1-3 \mathrm{~mm} \mathrm{Hg}$. The raised diastolic pulmonary gradient $(>7 \mathrm{~mm} \mathrm{Hg}$ ) in a given patient of PH-LHD suggests setting-in of pre-capillary component (pulmonary vascular pathology) over and above post-capillary component [13]. In one study the patients with TPG $>12 \mathrm{~mm} \mathrm{Hg}$ who had DPG $>7 \mathrm{~mm} \mathrm{Hg}$ had worse prognosis [18]. In contrast, another study of 1236 patients with cardiomyopathy and PH-LHD, elevated DPG was not associated with worse survival [19]. Pulmonary vascular resistance (PVR) of $\leq 3$ Wood units (WU) characterizes Ipc-PH, whereas PVR > $3 \mathrm{WU}$ is suggestive of $\mathrm{Cpc}-\mathrm{PH}$ or reactive $\mathrm{PH}$ in the setting of left heart disease (Figure 1). The latest ESC/ERS guidelines recommend combined use of DPG and PVR to differentiate between Ipc-PH and Cpc-PH in PH-LHD [20].

\section{Impact of pulmonary hypertension development on prognosis}

The development of $\mathrm{PH}$ in left heart disease is a marker of chronicity. Patients with PH-LHD typically have advanced disease and have poorer prognosis [11, 21]. Pulmonary hypertension is associated with decreased survival in HF-PEF and HF-REF $[4,9]$. In patients with PH-LHD, the right ventricular (RV) function further dichotomizes the risk. The presence of RV dysfunction in patients with PH-LHD is an ominous finding. Ghio et al. have reported RV dysfunction with high mPAP in $57 \%$ of their cohort of patients with dilated cardiomyopathy [21]. They found a significant inverse relationship between MPAP and RV
Table I. Updated clinical classification of pulmonary hypertension [1]

\begin{tabular}{|c|c|}
\hline 1 & Pulmonary arterial hypertension \\
\hline 1.1 & Idiopathic PAH \\
\hline 1.2 & Heritable PAH \\
\hline 1.2 .1 & BMPR2 \\
\hline 1.2 .2 & ALK-1, ENG, SMAD9, CAV1, KCNK3 \\
\hline 1.2 .3 & Unknown \\
\hline 1.3 & Drug and toxin induced \\
\hline 1.4 & Associated with: \\
\hline 1.4 .1 & Connective tissue disease \\
\hline 1.4 .2 & HIV infection \\
\hline 1.4 .3 & Portal hypertension \\
\hline 1.4 .4 & Congenital heart disease \\
\hline 1.4 .5 & Schistosomiasis \\
\hline $1^{\prime}$ & $\begin{array}{l}\text { Pulmonary veno-occlusive disease and/or } \\
\text { pulmonary capillary hemangiomatosis }\end{array}$ \\
\hline 1" & $\begin{array}{l}\text { Persistent pulmonary hypertension of the } \\
\text { newborn (PPHN) }\end{array}$ \\
\hline 2 & $\begin{array}{l}\text { Pulmonary hypertension due to left heart } \\
\text { disease }\end{array}$ \\
\hline 2.1 & Left ventricular systolic dysfunction \\
\hline 2.2 & Left ventricular diastolic dysfunction \\
\hline 2.3 & Valvular disease \\
\hline 2.4 & $\begin{array}{l}\text { Congenital/acquired left heart inflow/ } \\
\text { outflow tract obstruction and congenital } \\
\text { cardiomyopathies }\end{array}$ \\
\hline 3 & $\begin{array}{l}\text { Pulmonary hypertension due to lung diseases } \\
\text { and/or hypoxia }\end{array}$ \\
\hline 3.1 & Chronic obstructive pulmonary disease \\
\hline 3.2 & Interstitial lung disease \\
\hline 3.3 & $\begin{array}{l}\text { Other pulmonary diseases with mixed } \\
\text { restrictive and obstructive pattern }\end{array}$ \\
\hline 3.4 & Sleep-disordered breathing \\
\hline 3.5 & Alveolar hypoventilation disorders \\
\hline 3.6 & Chronic exposure to high altitude \\
\hline 3.7 & Developmental lung diseases \\
\hline 4 & $\begin{array}{l}\text { Chronic thromboembolic pulmonary hyperten- } \\
\text { sion (CTEPH) }\end{array}$ \\
\hline 5 & $\begin{array}{l}\text { Pulmonary hypertension with unclear multi- } \\
\text { factorial mechanisms }\end{array}$ \\
\hline 5.1 & $\begin{array}{l}\text { Hematologic disorders: chronic hemolytic } \\
\text { anemia, myeloproliferative disorders, } \\
\text { splenectomy }\end{array}$ \\
\hline 5.2 & $\begin{array}{l}\text { Systemic disorders: sarcoidosis, pulmonary } \\
\text { histiocytosis, lymphangioleiomyomatosis }\end{array}$ \\
\hline 5.3 & $\begin{array}{l}\text { Metabolic disorders: glycogen storage diseases, } \\
\text { Gaucher disease, thyroid disorders }\end{array}$ \\
\hline 5.4 & $\begin{array}{l}\text { Others: tumoral obstruction, fibrosing } \\
\text { mediastinitis, chronic renal failure, } \\
\text { segmental PH }\end{array}$ \\
\hline
\end{tabular}


Table II. Prevalence of pulmonary hypertension in left heart disease

\begin{tabular}{|lcc|}
\hline S. No. & Left sided heart disease & Prevalence of PH (\%) \\
\hline 1 & LV systolic dysfunction [3] & 60 \\
\hline 2 & LV diastolic dysfunction (PASP > 35 mm Hg) [4] & 83 \\
\hline 3 & Mitral stenosis (PASP $\geq 50 \mathrm{~mm} \mathrm{Hg}$ ) [5] & 38 \\
\hline 4 & Mitral regurgitation (PASP > $50 \mathrm{~mm} \mathrm{Hg}$ ) [6] & 23 \\
\hline 5 & Aortic stenosis (PASP > $50 \mathrm{~mm} \mathrm{Hg}$ ) [7] & 29 \\
\hline 6 & Aortic regurgitation (PASP $\geq 60 \mathrm{~mm} \mathrm{Hg}$ ) [8] & 16 \\
\hline
\end{tabular}

Note: The above percentages are only approximate values based on the quoted series. It must be emphasized that the occurrence of PH is dependent on severity and duration of left heart disease such that the PH is more common in patients in advanced stages of underlying left heart disease. Further, it is not necessary that all patients with similar severity of particular left heart disease will develop PH or if PH is present it is of equal severity. Nevertheless, the presence and severity of PH signifies poor prognosis. PASP-pulmonary arterial systolic pressure, $L V$ - left ventricular.

ejection fraction. Nonetheless many patients of dilated cardiomyopathy with normal mPAP had RV dysfunction. The presence of RV dysfunction gives prognostic information over and above provided by MPAP [21].

Pre-transplant $\mathrm{PH}$ is associated with higher early mortality and poor post-transplant survival. Therefore, assessment of severity of $\mathrm{PH}$ is important in determining the candidacy for heart transplantation (HT). In patients with PASP $\geq 50 \mathrm{~mm} \mathrm{Hg}$ and either TPG $\geq 15 \mathrm{~mm} \mathrm{Hg}$ or PVR $>3 \mathrm{WU}$, vasodilator challenge should be administered to see for reversibility of $\mathrm{PH}$. Patients showing reversibility have better prognosis than patients with fixed $\mathrm{PH}$. If initial acute vasodilator challenge is unsuccessful, medical management with diuretics, nitric oxide and inotropes and/or mechanical assist devices may be tried in an attempt to decrease PVR. If PVR fails to decrease by above measures, patient is deemed to have irreversible fixed $\mathrm{PH}[22]$. Severe fixed $\mathrm{PH}$ is a contraindica-

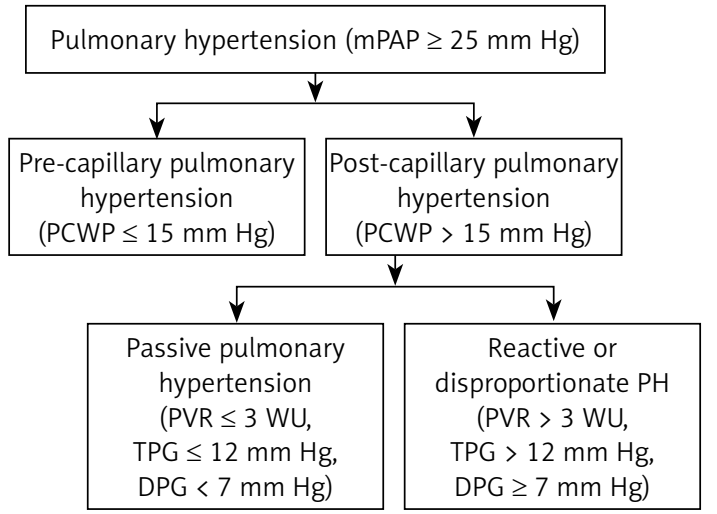

Figure 1. Hemodynamic definition of pulmonary hypertension

$T P G=m P A P-m P C W P, D P G=d P A P-m P C W P, D P G-$ diastolic pulmonary gradient, DPAP - diastolic pulmonary artery pressure, TPG - transpulmonary gradient, MPAP - mean pulmonary arterial pressure, MPCWP - mean pulmonary capillary wedge pressure, $P H$ - pulmonary hypertension, PVR - pulmonary vascular resistance, WU - Wood units. tion to HT. Oral sildenafil can be tried in patients with irreversible $\mathrm{PH}$ associated with heart failure in an attempt to decrease PVR and as a bridge to transplantation. In a study of 18 patients with severe LV dysfunction, sildenafil increased RV ejection fraction from $26 \pm 7 \%$ to $30 \pm 9 \%, p=0.008$ and decreased PVR from $5.3 \pm 1.9$ to $3.3 \pm 1.8 \mathrm{WU}$, $p=0.01$ over a median follow-up of 8.7 months. During follow-up, 5 patients had HT and 6 had LV assist device implantation. All patients showing significant response as evidenced by a decrease in PVR to < $3 \mathrm{WU}$ were alive at follow up compared to non responders who had $44 \%$ survival rate [23]. In a comparative study of 15 patients with severe $\mathrm{PH}$ receiving oral sildenafil therapy and 104 patients without severe $\mathrm{PH}$ who underwent heart transplantation, sildenafil was administered in severe $\mathrm{PH}$ group for $163 \pm 116$ days before HT, and $43 \pm 45$ days after HT. Sildenafil therapy resulted in significant decrease in PVR from $5.0 \pm 1.1$ to $3.0 \pm 1.6 \mathrm{WU}$, mean TPG decreased from $17.3 \pm 3.2$ to $10.2 \pm 4.1 \mathrm{~mm} \mathrm{Hg}$, and mPAP decreased from $43.9 \pm 12.5$ to $33.4 \pm 5.8 \mathrm{~mm} \mathrm{Hg}$, $p<0.01$. As a consequence all severe $\mathrm{PH}$ patients could undergo successful HT. Sildenafil could be withdrawn in most patients late after HT. Survival after HT was similar between both the groups [24].

Pulmonary hypertension and RV dysfunction after HT is associated with 3-5 fold increased risk of 30 day mortality. About $10-15 \%$ of all HT recipients develop RV dysfunction after transplantation. The addition of oral sildenafil in the post-operative period may allow early withdrawal of inhaled nitric oxide and intravenous drugs administered to reduce PAP [25].

\section{Persistent/residual pulmonary hypertension in valvular heart disease}

Most patients of valvular heart disease will have significant decrease in PAP after relief of 
valve stenosis/regurgitation [26, 27]. However, persistent/residual $\mathrm{PH}$ is observed in many patients even after successful relief of mitral valve obstruction or regurgitation by percutaneous balloon mitral valvotomy (BMV) or surgical mitral valve replacement [26]. Besides the presence of fixed component of $\mathrm{PH}$, other factors like suboptimal BMV, significant MR after BMV and patient-prosthesis mismatch are responsible for the persistence of $\mathrm{PH}$ even after therapeutic intervention [28-30].

In the study by Puri et al. residual $\mathrm{PH}$ correlated with functional capacity impairment 7 days after mitral valve replacement as determined by 6 min walk test [31]. Another study compared 287 patients with persistent $\mathrm{PH} 1$ year after BMV with 414 patients who did not have $\mathrm{PH}$ after BMV. The patients with persistent $\mathrm{PH}$ were older, had severe pre-BMV PH, increased Wilkin's mitral valve echocardiography scores and suboptimal BMV result. Importantly, on long term follow-up persistent $\mathrm{PH}$ group had more new onset heart failure and higher need for reintervention [32]. Further patients with atrial fibrillation have increased right atrial dilatation which further increases tricuspid annular dilatation and tricuspid regurgitation [33].

\section{Pathophysiology of pulmonary hypertension in left heart disease}

The increased pulmonary venous pressure results in disruption of alveolar-capillary walls termed alveolar-capillary stress failure, resulting in capillary leakage and acute alveolar edema [34]. This acute stage is reversible. However with chronically increased pulmonary venous pressure there is irreversible remodeling of the alveolar-capillary membrane as a compensatory mechanism to decrease the frequency and severity of potentially life-threatening pulmonary edema [35].

The remodeling affects both pulmonary venous and arterial system with thickening of the capillary endothelial and alveolar epithelial cell basement membranes and pulmonary veins. These changes reduce the permeability of the alveolar-capillary membrane to fluids, and prevent development of pulmonary edema. The process also results in muscularization of the arterioles and neointima formation along with medial hypertrophy of distal small pulmonary arteries leading to increased pulmonary vascular resistance $[36,37]$. Also lymphatic vessels are dilated [35]. With long-standing disease, pulmonary edema becomes less frequent and the clinical picture is dominated by development of $\mathrm{PH}$ and right heart failure (Figure 2).

The development of pulmonary vascular disease is variable, with some patients developing severe $\mathrm{PH}$ while others being spared of $\mathrm{PH}$ despite similar rises in PCWP. While why this happens is unknown, some factors may be responsible. The patients with large compliant left atria may be less prone to development of pulmonary edema and ultimately less severe $\mathrm{PH}$. Also development of AF may make them more prone to develop $\mathrm{PH}$.

\section{Pulmonary function abnormalities}

The gas diffusion across the alveolar capillary membrane is decreased in $\mathrm{HF}$, the degree of impairment depending on severity of HF [38]. Patients with mitral valve disease have decreased FVC, FEV ${ }_{1}$ and diffusion capacity of lung for carbon monoxide $\left(\mathrm{DL}_{\mathrm{CO}}\right)$ and increase in residual volume [39]. Structural changes in the alveolar-capillary membrane decrease diffusion capacity of the lung with resultant impedance to gas transfer contributing to exercise intolerance.

\section{Genetics}

The influence of genetics in development of idiopathic PH (WHO Group 1) is undisputed. Genetic studies have shown that approximately $80 \%$ of patients with familial pulmonary arterial hypertension (PAH) and $25 \%$ of patients with sporadic $\mathrm{PAH}$ carry mutations in the bone morphogenetic protein receptor 2 (BMPR II) [1]. But there are no studies which have investigated a link between PH-LHD and BMPR II mutations. Endothelin-1 gene polymorphisms have been shown to induce pulmonary hypertension in idiopathic PAH [40, 41]. Although there is no concrete evidence for genetic predisposition, attempt is being made to find predisposing genetic factors in PH-LHD. Serotonin and its transporter protein (5-HTT) have vasoactive and mitogenic properties. Homozygous patients for the long variant of 5-HTT have been shown to be associated with elevated PAP in heart failure [42].

\section{Two-dimensional and Doppler echocardiography}

Echocardiography is used for the diagnosis and quantification of severity of left heart disease like left ventricular systolic/diastolic dysfunction and valvular heart disease and highlights features suggestive of $\mathrm{PH}$ like right atrial (RA) enlargement and RV dilatation, hypertrophy or dysfunction. Echocardiography is a semi-quantitative screening tool for diagnosing PH [43-47]. Doppler echocardiography is used to estimate the right ventricular systolic pressure (RVSP) from tricuspid regurgitation velocity jet by adding estimated RA pressure. The ancillary signs of RV involvement must be present in addition to elevated RVSP to diagnose $\mathrm{PH}$ (Table III) [48]. Also peak early diastolic and end diastolic velocities of pulmonary regurgitation (PR) jet continuous wave Doppler trace significantly 


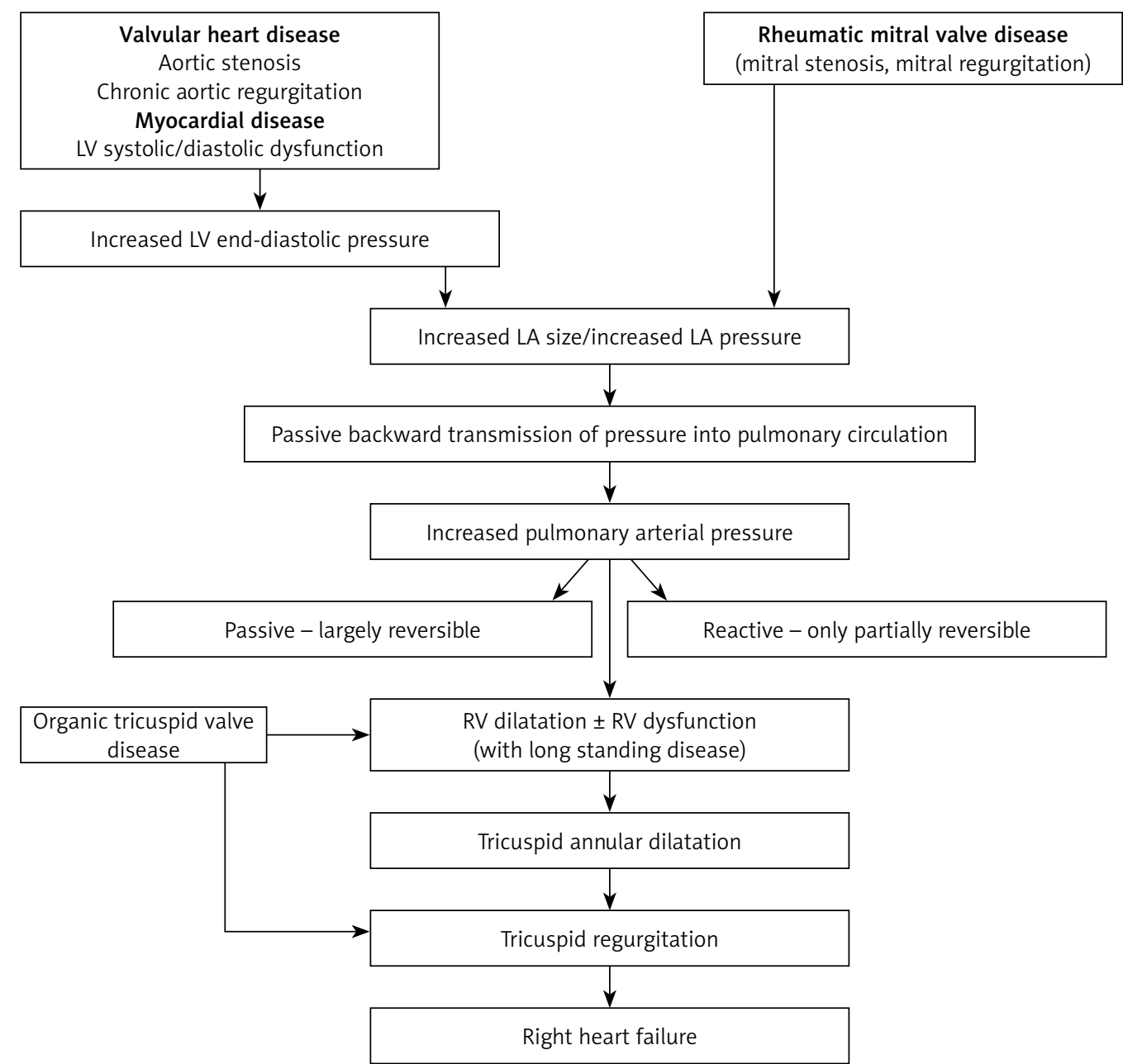

Figure 2. Pathophysiology of pulmonary hypertension and right heart failure in left heart disease

correlate with mean and end diastolic PAP respectively [49] (Figure 3).

The grading of severity of $\mathrm{PH}$ is ideally done by RHC especially when specific pulmonary vasodilator therapy is planned or in the event of diagnostic ambiguity. Although only modest correlation of Doppler derived PA pressures and $\mathrm{RHC}$ measured pressures has been reported in earlier studies $(r \approx 0.7)$ [50], a recent study of 667 patients undergoing both RHC and transthoracic echocardiography has reported a high correlation of invasive mean PAP and Doppler derived systolic PAP in patients with interpretable TR jets. The degree of correlation decreased in patients who had partially visible TR jet envelope, signifying the importance of TR jet envelope quality in correctly estimating systolic PAP [51]. Echocardiographic features suggesting post-capillary $\mathrm{PH}$ include larger left heart chambers compared to right heart chambers with LV forming the apex, LV eccentricity index $<1.2$ and E/E' $\geq 10$ [52]. The Doppler derived systolic PAP can be monitored periodically non-invasively along with RV assessment by echocardiography.
However, the degree of improvement in RV size, septal position and RV systolic function measured by tricuspid annulus plane systolic excursion (TAPSE), rather than Doppler-estimated PASP in response to $\mathrm{PH}$-specific therapy are predictive of outcomes in Group 1 PH [53]. TAPSE has also been shown to assist in risk stratification in acute pulmonary embolism [54]. Although not specifically studied in PH-LHD, it may be reasonable to follow these patients with regards to above parameters. Other parameters like PA elastance can be calculated by echocardiography which shows moderate correlation with RHC-derived PVR [55].

\section{Right heart catheterization}

Right heart catheterization is the gold standard for diagnosis of $\mathrm{PH}$ and is recommended in patients with PH-LHD $[20,56]$. When reliable PCWP cannot be measured on RHC, left heart catheterization is recommended. Right heart catheterization can also assist in ruling out other causes of $\mathrm{PH}[3,20]$. Exercise testing may be helpful in evaluation of patients with borderline $\mathrm{PH}$ associated with left heart disease [56]. Further, fluid challenge with fluid load of 
Table III. Echocardiographic parameters for assessment of right ventricle [43-47]

\begin{tabular}{|c|c|c|c|}
\hline Method & Normal range & $\begin{array}{l}\text { Abnormal } \\
\text { value }\end{array}$ & Remarks \\
\hline $\begin{array}{l}\text { Inferior vena cava diameter } \\
\text { and inspiratory collapse }\end{array}$ & $\begin{array}{c}\leq 21 \mathrm{~mm}, \\
>>50 \% \\
\text { inspiratory } \\
\text { collapse } \\
\text { with a sniff } \\
\text { suggests } \\
\text { normal RA } \\
\text { pressure }\end{array}$ & $>21 \mathrm{~mm}$ & $\begin{array}{l}\text { Decreased inspiratory collapse with a sniff }<50 \% \\
\text { suggests high RA pressure }(10-20 \mathrm{~mm} \mathrm{Hg})\end{array}$ \\
\hline Right atrial area (end-systole) & $14-15 \mathrm{~cm}^{2}$ & $>18 \mathrm{~cm}^{2}$ & $\begin{array}{l}\text { RA enlargement is an indirect measure of RV } \\
\text { dysfunction and suggests chronic RA remodeling }\end{array}$ \\
\hline RV basal diameter & $25-41 \mathrm{~mm}$ & $>41 \mathrm{~mm}$ & $\begin{array}{c}\text { Linear dimension of basal RV in } 4 \text { chamber view } \\
\text { measured in basal one-third of RV inflow at end- } \\
\text { diastole }\end{array}$ \\
\hline RV mid-cavity diameter & $19-35 \mathrm{~mm}$ & $>35 \mathrm{~mm}$ & $\begin{array}{c}\text { Transverse RV diameter in middle third of RV } \\
\text { inflow }\end{array}$ \\
\hline RV base-to-apex diameter & $59-83 \mathrm{~mm}$ & $>83 \mathrm{~mm}$ & RV foreshortening to be avoided \\
\hline RV/LV basal diameter ratio & $<1$ & $>1.1$ & Suggests RV dilatation \\
\hline RV free wall thickness & $1-5 \mathrm{~mm}$ & $>5 \mathrm{~mm}$ & $\begin{array}{l}\text { True thickness avoiding trabeculations. Measured } \\
\text { from subcostal and parasternal long-axis views }\end{array}$ \\
\hline $\begin{array}{l}\text { Tricuspid annular plane } \\
\text { systolic excursion }\end{array}$ & $20 \pm 2.8 \mathrm{~mm}$ & $<17 \mathrm{~mm}$ & $\begin{array}{c}\text { Measure of RV longitudinal function. By M-mode } \\
\text { echo directed at lateral tricuspid annulus in } \\
4 \text { chamber view }\end{array}$ \\
\hline RV fractional area change & $47-51 \%$ & $<35 \%$ & $\begin{array}{c}\text { Measured in } 4 \text { chamber view as change in RV } \\
\text { area from diastole to systole }\end{array}$ \\
\hline TVI- S' wave velocity & $14-15 \mathrm{~cm} / \mathrm{s}$ & $<9.5 \mathrm{~cm} / \mathrm{s}$ & Lateral tricuspid annular systolic tissue velocity \\
\hline RV MPI & $0.28 \pm 0.04$ & $>0.40$ & Not limited by RV geometry \\
\hline RVOT acceleration time (AT) & $>110 \mathrm{~ms}$ & $\begin{array}{l}<105 \mathrm{~ms} \\
\text { and/or } \\
\text { midsystolic } \\
\text { notching }\end{array}$ & Inverse relationship between AT and mean PAP \\
\hline Interventricular septum & $\begin{array}{l}\text { Normally IV } \\
\text { septum bows } \\
\text { towards RV }\end{array}$ & $\begin{array}{l}\text { Flattening/ } \\
\text { bowing of } \\
\text { IV septum } \\
\text { towards LV }\end{array}$ & Suggestive of increased RV pressures \\
\hline $\begin{array}{l}\text { LV eccentricity index in systole } \\
\text { or diastole }\end{array}$ & 1 & $>1.1$ & $\begin{array}{l}\text { LV antero-posterior to septo-lateral diameters } \\
\text { ratio just above papillary muscles in short-axis }\end{array}$ \\
\hline $\begin{array}{l}\text { Early diastolic pulmonary } \\
\text { regurgitant velocity }\end{array}$ & $<1 \mathrm{~m} / \mathrm{s}$ & $>1 \mathrm{~m} / \mathrm{s}$ & Estimates mean PAP \\
\hline $\begin{array}{l}\text { Late diastolic pulmonary } \\
\text { regurgitant velocity }\end{array}$ & $<1 \mathrm{~m} / \mathrm{s}$ & $>1 \mathrm{~m} / \mathrm{s}$ & $\begin{array}{c}\text { Estimates pulmonary artery end-diastolic } \\
\text { pressure }\end{array}$ \\
\hline Pulmonary artery diameter & - & $>25 \mathrm{~mm}$ & Suggests pulmonary artery dilatation \\
\hline
\end{tabular}

$500 \mathrm{ml}$ can unmask underlying LV diastolic dysfunction and occult pulmonary venous hypertension by documenting increased LVEDP to $>15 \mathrm{~mm} \mathrm{Hg}$ in patients where baseline values were normal [57].

The presence and quantification of $\mathrm{PH}$ may explain patient symptoms, affect management decisions and help in assessing prognosis. Resting $\mathrm{PAP}>50 \mathrm{~mm} \mathrm{Hg}$ is Class lla indication for intervention in asymptomatic severe mitral stenosis (ESC guidelines) [58] and asymptomatic severe mi- tral regurgitation (MR) (ESC and AHA guidelines) $[58,59]$. Exercise induced $\mathrm{PH}$ in asymptomatic patients with valvular heart disease and in patients with secondary MR may provide additional prognostic information (Table IV) [60-73].

\section{Management}

The management of $\mathrm{PH}$-LHD predominantly involves the treatment of underlying left heart dis- 


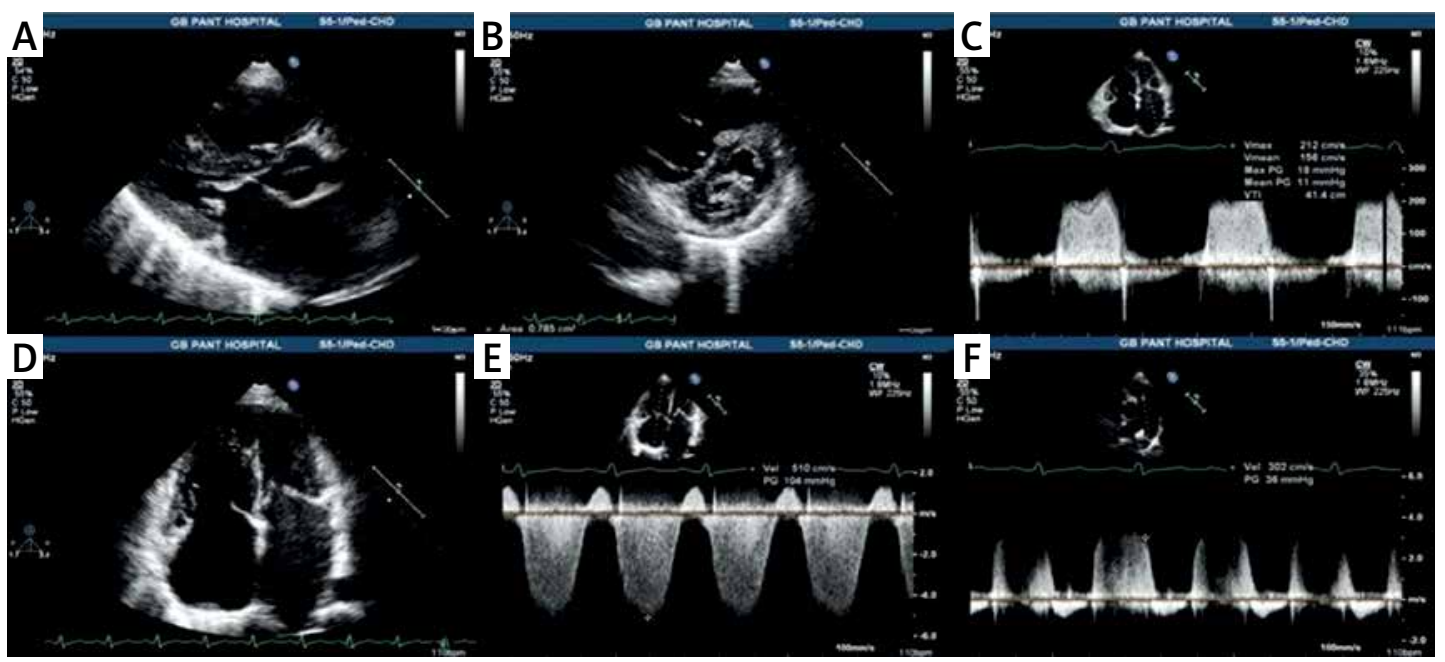

Figure 3. Echocardiography of patient in Fig. 3 of rheumatic heart disease with severe mitral stenosis in normal sinus rhythm showing: A - thickened mitral leaflets with diastolic doming of anterior mitral leaflet with marked left atrial dilatation, $\mathbf{B}$ - mitral valve in short-axis in diastole showing fused medial and lateral commissures with area of $0.78 \mathrm{~cm}^{2}$ by planimetry, $\mathbf{C}$ - measurement of mean transmitral gradient of $11 \mathrm{~mm} \mathrm{Hg}, \mathbf{D}$ - dilated left atrium, right atrium and right ventricle, E-CW Doppler of TR jet showing peak velocity of $5.1 \mathrm{~m} / \mathrm{s}$ with calculated RVSP of $104 \mathrm{~mm} \mathrm{Hg}$ plus right atrial pressure, $\mathrm{F}$ - end-diastolic velocity of pulmonary regurgitation signal of $3 \mathrm{~m} / \mathrm{s}$ with calculated pulmonary artery end diastolic pressure of $36 \mathrm{~mm} \mathrm{Hg}$ plus right atrial pressure

ease. Aggressive medical management of HF-REF primarily includes diuretics, angiotensin converting enzyme inhibitors, angiotensin receptor blockers, $\beta$-blockers and mineralocorticoid receptor antagonists [74]. Digoxin can be used as second line drug in patients with persisting symptoms despite being on above mentioned drugs [74]. Corrective valve surgery/percutaneous intervention is recommended and is usually associated with resolution of $\mathrm{PH}$ [59]. The recent approval of new drugs for pulmonary artery hypertension has rekindled the interest in the treatment of $\mathrm{PH}$. However the new drugs introduced are for WHO categories Group 1 $\mathrm{PH}$ and Group $4 \mathrm{PH}$. Unfortunately despite being the commonest cause of raised pulmonary artery pressures, $\mathrm{PH}$-LHD remains an under-studied disease with no specific treatment available. Despite promising results in acute hemodynamic studies with some pulmonary vasodilators, the intermediate term results have been disappointing. The reasons for this are many and include: 1) the non-specific selection of patients with systolic and diastolic dysfunction in most studies without adequate segregation based on baseline pulmonary artery pressures except in few studies [75, 76], 2) no studies are available on $\mathrm{PH}$ associated with valvular heart disease, an important subset of $\mathrm{PH}$ LHD. At present, there is no evidence that $\mathrm{PH}$ specific drug therapy is effective in patients with $\mathrm{PH}$ LHD. Further, the European Society of Cardiology/ European Respiratory Society guidelines do not recommend the use of drugs approved for Group 1 $\mathrm{PH}$ in PH-LHD due to the lack of evidence [3].

Nitric oxide (NO) and prostacyclin are potent pulmonary vasodilators which improve pulmonary hemodynamics by decreasing pulmonary vascular resistance [77]. The endothelin system is activated in chronic heart failure and elevated plasma ET-1 levels correlate with hemodynamic severity of heart failure and correlate with mortality [78]. Plasma ET-1 acts via two receptor subtypes (ET and $\mathrm{ET}_{\mathrm{B}}$ ) which leads to pulmonary vasoconstriction, and vascular smooth muscle cell proliferation. In small studies using the dual endothelin-1 receptor antagonist bosentan and tezosentan, and selective endothelin A receptor antagonist darusentan, there was an acute improvement in mean PAP, right atrial pressure, PCWP, and cardiac output [78-81]. Intravenous bosentan led to acute improvement in pulmonary hemodynamics in 24 patients with chronic heart failure [78]. In a large placebo-controlled study of patients with acute decompensated heart failure, intravenous tezosentan led to an acute reduction in left ventricular filling pressures, and increased cardiac index but did not result in improvement in dyspnea or pulmonary edema endpoints [78, 82-84]. Further in another large study of 1435 acute HF patients with persistent dyspnea, the dyspnea score, incidence of death and worsening HF was similar between intravenous tezosentan for 24-72 h group and placebo [85]. A number of longer-term studies have not confirmed a benefit for the use of endothelin receptor antagonists in patients with $\mathrm{PH}$ associated with HF. However, there was a trend toward reduced HF mortality and morbidity with bosentan [86]. Currently the use of endothelin receptor antagonists is not recommended for the treatment of $\mathrm{PH}$ associated with left heart disease. 
Table IV. Role of exercise in evaluation of valvular disease

\begin{tabular}{|c|c|c|c|}
\hline $\begin{array}{l}\text { Role of exercise in mitral } \\
\text { stenosis }\end{array}$ & $\begin{array}{l}\text { Role of exercise in aortic } \\
\text { stenosis }\end{array}$ & $\begin{array}{l}\text { Role of exercise } \\
\text { in primary mitral } \\
\text { regurgitation (MR) }\end{array}$ & $\begin{array}{l}\text { Role of exercise in } \\
\text { secondary mitral } \\
\text { regurgitation }\end{array}$ \\
\hline $\begin{array}{l}\text { - Exercise results in in- } \\
\text { crease in LA pressure, } \\
\text { transmitral mean pres- } \\
\text { sure gradient and systol- } \\
\text { ic PAP [60] } \\
\text { - Patients with low LA } \\
\text { compliance are more } \\
\text { symptomatic and show } \\
\text { exaggerated increase in } \\
\text { PAP with exercise. Steep } \\
\text { E wave downslope is re- } \\
\text { corded in such patients } \\
\text { on continuous wave } \\
\text { Doppler trace on mitral } \\
\text { valve interrogation re- } \\
\text { sulting in overestimation } \\
\text { of calculated valve area } \\
\text { by pressure half-time } \\
\text { method [61] } \\
\text { - In asymptomatic patients } \\
\text { exercise induced increase } \\
\text { in RVSP to > } 60 \text { mm Hg } \\
\text { should prompt reassess- } \\
\text { ment of symptoms [59] } \\
\text { - Increase in systolic PAP } \\
\geq 90 \% \text { during exercise } \\
\text { stress test is associat- } \\
\text { ed with development of } \\
\text { dyspnea in asymptom- } \\
\text { atic MS patients and } \\
\text { increased need for mi- } \\
\text { tral valve intervention } \\
\text { during follow up [62] }\end{array}$ & $\begin{array}{l}\text { - Severe AS patients with } \\
\text { resting elevated PAP } \\
\text { ( } 50 \mathrm{~mm} \mathrm{Hg} \text { ) are often } \\
\text { symptomatic and have } \\
\text { poor outcome [63, 64] } \\
\text { - Exercise stress echocar- } \\
\text { diography is useful in } \\
\text { unmasking patients with } \\
\text { asymptomatic severe AS } \\
\text { who are at high risk of } \\
\text { future cardiac events [65] } \\
\text { - Besides poor prognostic } \\
\text { markers like increase of } \\
\text { mean pressure gradient } \\
\text { increase of }>20 \text { mm Hg } \\
\text { and lack of contractile } \\
\text { reserve on exercise, ex- } \\
\text { ercise PH has incremen- } \\
\text { tal value in identifying } \\
\text { high-risk asymptomatic } \\
\text { AS patients [66, } 67] \\
\text { - Exercise PH gives addi- } \\
\text { tional prognostic infor- } \\
\text { mation on top of exer- } \\
\text { cise induced increase } \\
\text { in aortic trans-valvular } \\
\text { gradient } \\
\text { - Exercise stress echocar- } \\
\text { diography induced PH } \\
\text { (systolic PAP }>60 \text { mm Hg) } \\
\text { is more common than } \\
\text { resting PH in asymptom- } \\
\text { atic, adversely affecting } \\
\text { the prognosis [66, } 68] \\
\text { In asymptomatic severe } \\
\text { AS patients exercise } \\
\text { stress echocardiography } \\
\text { induced PH is a predictor } \\
\text { of development of symp- } \\
\text { toms, occurrence of rest- } \\
\text { ing PH and doubling of } \\
\text { risk of cardiac events [68] }\end{array}$ & $\begin{array}{l}\text { - Exercise PH (> } 60 \mathrm{~mm} \\
\mathrm{Hg} \text { ) is frequent (46\% pa- } \\
\text { tients) in asymptomatic } \\
\text { moderate and severe de- } \\
\text { generative MR patients } \\
\text { and is associated with } \\
\text { early development of } \\
\text { symptoms [69] } \\
\text { - Exercise induced in- } \\
\text { crease in MR severity is } \\
\text { a strong predictor of ex- } \\
\text { ercise PH [69] } \\
\text { - Exercise PH is an inde- } \\
\text { pendent predictor of } \\
\text { lower event-free survival } \\
\text { and need for mitral valve } \\
\text { surgery } \\
\text { - Pre-operative exercise } \\
\text { PH (SPAP > } 60 \text { mm Hg) } \\
\text { is associated with sig- } \\
\text { nificantly reduced post } \\
\text { operative event free } \\
\text { survival including atrial } \\
\text { fibrillation, stroke, car- } \\
\text { diac-related hospitaliza- } \\
\text { tion or death [70] } \\
\text { - Exercise echo is not } \\
\text { recommended in symp- } \\
\text { tomatic patients and in } \\
\text { those with reduced LVEF } \\
\text { (<60\%) [71] } \\
\text { - Mitral valve surgery is } \\
\text { a Class llb indication in as- } \\
\text { ymptomatic patients with } \\
\text { exercise PH } \geq 60 \text { mm Hg } \\
\text { (ESC guidelines) [58] }\end{array}$ & $\begin{array}{l}\text { - Although ERO of MR } \\
\geq 20 \mathrm{~mm}^{2} \text { at rest is a pre- } \\
\text { dictor of cardiac death, } \\
\text { evaluation of ischemic } \\
\text { MR at rest in CHF under- } \\
\text { estimates the severity of } \\
\text { MR and its prognostic } \\
\text { implications [72] } \\
\text { - Exercise induced in- } \\
\text { crease in ERO of MR of } \\
\geq 13 \mathrm{~mm}^{2} \text { and systolic } \\
\text { PAP increase of } 21 \text { mm Hg } \\
\text { are predictors of future } \\
\text { CHF hospitalization and } \\
\text { cardiac mortality [58, 73] } \\
\text { - The increase in LV filling } \\
\text { pressures during exer- } \\
\text { cise in CHF patients is } \\
\text { transmitted to the pul- } \\
\text { monary vasculature re- } \\
\text { sulting in rise of systolic } \\
\text { PAP. Exercise induced in- } \\
\text { crease in MR is associat- } \\
\text { ed with increase in pul- } \\
\text { monary artery pressure } \\
\text { - Exercise induced in- } \\
\text { crease in systolic PAP } \\
\text { can occur in secondary } \\
\text { MR associated with both } \\
\text { LV systolic and diastolic } \\
\text { dysfunction [58] }\end{array}$ \\
\hline
\end{tabular}

AS - aortic stenosis, CHF - chronic congestive heart failure, ERO - effective regurgitant orifice, LA - left atrium, $L V$ - left ventricle, $L V E F$ - left ventricular ejection fraction, $M S$ - mitral stenosis, MR - mitral regurgitation, PAP - pulmonary artery pressure, $P H$ - pulmonary hypertension, RV - right ventricle.

It is likely that the patients who have PH disproportionate to their underlying left heart disease will likely benefit from specific $\mathrm{PH}$ therapy. However, many of the trials included all patients with congestive heart failure, rather than patients specifically with associated $\mathrm{PH}$. Only few small studies have studied effect of sildenafil in HF patients with $\mathrm{PH}[87,88]$. Although hypothetically pulmonary vasodilatation may result in increased cardiac filling resulting in increased pulmonary venous congestion, acute hemodynamic study by Lepore et al. showed that PDE-5 inhibition with sildenafil improves cardiac output by balanced pulmonary and systemic vasodilatation [88]. Data from FIRST study suggests that epoprostenol use in systolic heart failure is associated with increased mortality despite decrease in PVR and PCWP and increased cardiac output [89]. Similarly there was increased risk of worsening CHF with endothelin antagonist bosentan in systolic HF initially [86]. However patients who continued treatment for 6 months there was improvement in primary endpoint [86]. Perhaps aggressive diuretic therapy before initiation of pulmonary vasodilator therapy and use of drugs which result in both pulmonary and systemic vasodilatation will be beneficial.

PDE-5 inhibitors such as sildenafil lead to pulmonary vasodilatation and have anti-prolif- 
erative action on pulmonary vascular smooth muscle cells. In chronic heart failure, sildenafil acutely lowers PVR and pulmonary arterial pressures, and improves endothelium dependent flow-mediated pulmonary vasodilatation, with a sustained clinical benefit at 6 months $[75,87$, 88, 90]. In CHF with $\mathrm{PH}$, sildenafil is associated with increased 6MWT distance, and improved pulmonary hemodynamics at 12 weeks $[87,88]$. Longer-term studies have shown that sildenafil is associated with improvement in exercise capacity, cardiac output during and skeletal muscle blood flow during exercise [87]. However, sildenafil in HF-PEF did not result in any significant improvement in exercise capacity or clinical status over 24 weeks [76]. Despite these promising results, the routine use of sildenafil in patients with PH associated with left heart disease cannot be recommended.

Riociguat is a novel soluble guanylate cyclase (sGC) stimulator that sensitizes SGC to endogenous $\mathrm{NO}$ and directly stimulates SGC independently of NO, thereby increasing NO by dual means. In addition to causing vasodilatation, it has antifibrotic, anti-proliferative, and anti-inflammatory effects [91]. Although approved for Group 1 and 4 $\mathrm{PH}$, a recent study of 201 patients having $\mathrm{PH}$ due to systolic heart failure riociguat did not result in any significant change in mean PAP, biomarkers, and CV death or hospitalization versus placebo despite improvement in stroke volume and cardiac index and decrease in pulmonary vascular resistance and systemic vascular resistance [92].

\section{Conclusions}

Pulmonary hypertension is common in patients with left heart disease, and is associated with increased morbidity and mortality. Pathophysiologic mechanisms are complex and comprise of both passive and active components secondary to left atrial hypertension. Echocardiography is screening tool for initial evaluation of patients with PH-LHD. Management of $\mathrm{PH}$ focuses upon the treatment of the underlying left heart disease, and associated comorbidities. Although there is no evidence for routine use of $\mathrm{PH}$ specific therapies in $\mathrm{PH}-\mathrm{LHD}$, there is some suggestion that PDE-5 inhibitors may be useful especially in certain subsets.

\section{Future directions}

At present management of PH-LHD is far from satisfactory. No clear cut guidelines exist as how to manage and follow-up PH-LHD patients. As some patients with similar left heart disease develop $\mathrm{PH}$, while others do not, the factors which predispose to the development of $\mathrm{PH}$ need to be elucidated. As genetic predisposition is proven in idiopathic pulmonary arterial hypertension, the role of genetics in PH-LHD needs to be studied. There is a need to better define the echocardiographic markers to differentiate between Ipc-PH and $\mathrm{Cpc}-\mathrm{PH}$. As repeated catheterization studies to see the effect of management strategies may be impractical, better echocardiographic prognostic parameters need to be defined. The HF-PEF and HF-REF patients with $\mathrm{PH}$ need to be studied separately. Studies of pulmonary vasodilators need to dichotomize patients according to PAP rather than non-specific inclusion of a particular left heart disease. Trials of pulmonary vasodilators in $\mathrm{PH}$ associated with valvular heart disease need to be conducted. Future studies targeting lung structural and vascular remodeling in $\mathrm{PH}$ rather than only vasodilators will be necessary [93].

\section{Conflict of interest}

The authors declare no conflict of interest.

\section{References}

1. Simonneau G, Gatzoulis MA, Adatia I, et al. Updated clinical classification of pulmonary hypertension. J Am Coll Cardiol 2013; 62: 34-41.

2. Dupuis J, Guazzi M. Pathophysiology and clinical relevance of pulmonary remodeling in pulmonary hypertension due to left heart diseases. Can J Cardiol 2015; 31: 416-29.

3. Galie N, Hoeper MM, Humbert M, et al. Guidelines for the diagnosis and treatment of pulmonary hypertension: the task force for the diagnosis and treatment of pulmonary hypertension of the European Society of Cardiology (ESC) and the European Respiratory Society (ERS), endorsed by the International Society of Heart and Lung Transplantation (ISHLT). Eur Heart J 2009; 30: 2493-537.

4. Lam CSP, Roger VL, Rodeheffer RJ, Borlaug BA, Enders FT, Redfield MM. Pulmonary hypertension in heart failure with preserved ejection fraction: a community-based study. J Am Coll Cardiol 2009; 53: 1119-26.

5. Fawzy ME, Hassan W, Stefadouros M, Moursi M, Shaer FE, Chaudhary MA. Prevalence and fate of severe pulmonary hypertension in 559 consecutive patients with severe rheumatic mitral stenosis undergoing mitral balloon valvotomy. J Heart Valve Dis 2004; 13: 942-8.

6. Patel H, Desai M, Tuzcu EM, Griffin B, Kapadia S. Pulmonary hypertension in mitral regurgitation. J Am Heart Assoc 2014; 3: e000748.

7. Malouf JF, Sarano ME, Pellikka PA, et al. Severe pulmonary hypertension in patients with severe aortic valve stenosis: clinical profile and prognostic implications. J Am Coll Cardiol 2002; 40: 789-95.

8. Khandhar S, Varadarajan P, Turk R, et al. Survival benefit of aortic valve replacement in patients with severe aortic regurgitation and pulmonary hypertension. Ann Thorac Surg 2009; 88: 752-7.

9. Abramson SV, Burke JF, Kelly Jr JJ, et al. Pulmonary hypertension predicts mortality and morbidity in patients with dilated cardiomyopathy. Ann Intern Med 1992; 116: 888-95. 
10. Corte TJ, McDonagh TA, Wort SJ. Pulmonary hypertension in left heart disease: a review. Int J Cardiol 2012; 156: 253-8.

11. Fang JC, DeMarco T, Givertz MM, et al. World Health Organization Pulmonary Hypertension Group 2: pulmonary hypertension due to left heart disease in the adult - a summary statement from the Pulmonary Hypertension Council of the International Society for Heart and Lung Transplantation. J Heart Lung Transplant 2012; 31: 913-33.

12. Guazzi M, Borlaug BA. Pulmonary hypertension due to left heart disease. Circulation 2012; 126: 975-90.

13. Vachiery J, Adir Y, Barberà J, et al. Pulmonary hypertension due to left heart diseases. J Am Coll Cardiol 2013; 62: D100-8.

14. Kjaergaard J, Akkan D, Iversen KK, et al. Prognostic importance of pulmonary hypertension in patients with heart failure. Am J Cardiol 2007; 99: 1146-50.

15. Badesch DB, Champion HC, Sanchez MAG, et al. Diagnosis and assessment of pulmonary arterial hypertension. J Am Coll Cardiol 2009; 54: S55-66.

16. Budev MM, Arroliga AC, Jennings CA. Diagnosis and evaluation of pulmonary hypertension. Cleve Clin J Med 2003; 70: S9-17.

17. Fox C, Kalarickal PL, Yarborowgh MJ, Jin JY. Perioperative management including new pharmacological vistas for patients with pulmonary hypertension for noncardiac surgery. Curr Opin Anaesthesiol 2008; 21: 467-72.

18. Gerges C, Gerges M, Lang MB, et al. Diastolic pulmonary vascular pressure gradient: a predictor of prognosis in "out-of-proportion" pulmonary hypertension. Chest 2013; 143: 758-66.

19. Tampakakis E, Leary PJ, Selby VN, et al. The diastolic pulmonary gradient does not predict survival in patients with pulmonary hypertension due to left heart disease. JACC Heart Fail 2015; 3: 9-16.

20. Galie N, Humbert M, Vachiery J, et al. 2015 ESC/ERS Guidelines for the diagnosis and treatment of pulmonary hypertension. Eur Heart J 2016; 37: 67-119.

21. Ghio S, Gavazzi A, Campana C, et al. Independent and additive prognostic value of right ventricular systolic function and pulmonary artery pressure in patients with chronic heart failure. J Am Coll Cardiol 2001; 37 183-8.

22. Mehra MR, Canter CE, Hannan ME, et al. The 2016 International Society for Heart Lung Transplantation listing criteria for heart transplantation: a 10-year update. J Heart Lung Transpl 2016; 35: 1-23.

23. de Groote P, Asri CE, Fertin M, et al. Sildenafil in heart transplant candidates with pulmonary hypertension. Arch Cardiovasc Dis 2015; 108: 375-84.

24. Pons J, Leblanc MH, Bernier M, et al. Effects of chronic sildenafil use on pulmonary hemodynamics and clinical outcomes in heart transplantation. J Heart Lung Transplant 2012; 31: 1281-7.

25. Sansone F, Rinaldi M. Oral sildenafil: potential role in heart transplantation. Review of the literature and personal experience. J Cardiol 2010; 55: 291-5.

26. Walls MC, Cimino N, Bolling SF, Bach DS. Persistent pulmonary hypertension after mitral valve surgery: does surgical procedure affect outcome? J Heart Valve Dis 2008; 17: 1-9.

27. Tracy GP, Proctor MS, Hizny CS. Reversibility of pulmonary artery hypertension in aortic stenosis after aortic valve replacement. Ann Thorac Surg 1990; 50: 89-93.

28. Dev V, Shrivastava S. Time course of changes in pulmonary vascular resistance and the mechanism of regres- sion of pulmonary arterial hypertension after balloon mitral valvuloplasty. Am J Cardiol 1991; 67: 439-42.

29. Levine MJ, Weinstein JS, Diver DJ, et al. Progressive improvement in pulmonary vascular resistance after percutaneous mitral valvuloplasty. Circulation 1989; 79 : 1061-7.

30. Li M, Dumesnil JG, Mathieu P, Pibarot P. Impact of valve prosthesis patient mismatch on pulmonary arterial pressure after mitral valve. J Am Coll Cardiol 2005; 45: 1034-40.

31. Puri S, Mehta V, Ahmed F, et al. Correlation of early functional capacity with biventricular function and residual pulmonary artery hypertension following mitral valve replacement surgery in patients with rheumatic mitral valve disease. J Cardiopulm Rehabil Prev 2013; 33: 244-8.

32. Nair KKM, Pillai HS, Titus T, et al. Persistent pulmonary artery hypertension in patients undergoing balloon mitral valvotomy. Pulm Circ 2013; 3: 426-31.

33. Shiran A, Sagie A. Tricuspid regurgitation in mitral valve disease. Incidence, prognostic implications, mechanism, and management. J Am Coll Cardiol 2009; 53: 401-8.

34. Guazi M, Galie N. Pulmonary hypertension in left heart disease. Eur Respir Rev 2012; 21: 338-46.

35. Gehlbach BK, Geppert E. The pulmonary manifestations of left heart failure. Chest 2004; 125: 669-82.

36. Haworth SG, Hall SM, Patel M. Peripheral pulmonary vascular and airway abnormalities in adolescents with rheumatic mitral stenosis. Int J Cardiol 1998; 18: 405-16.

37. Kay JM, Edwards FR. Ultrastructure of the alveolar-capillary wall in mitral stenosis. J Pathol 1973; 111: 239-45.

38. Guazzi M. Alveolar gas diffusion abnormalities in heart failure. J Card Fail 2008; 14: 695-702.

39. Rhodes KM, Evemy K, Nariman S, Gibson GJ. Relation between severity of mitral valve disease and results of routine lung function tests in non-smokers. Thorax 1982; 37: 751-5.

40. Ibrahim E, Kassem A, Zakaria N. The role of the biomarker and the genetic polymorphism of endothelin-1 in pulmonary arterial hypertension among Egyptians. Egyptian J Chest Dis Tuberculosis 2012; 61: 495-500.

41. Calabro P, Limongelli G, Maddaloni V, et al. Analysis of endothelin-1 and endothelin-1 receptor A gene polymorphisms in patients with pulmonary arterial hypertension. Intern Emerg Med 2012; 7: 425-30.

42. Olson TP, Snyder EM, Frantz RP, Turner ST, Johnson BD. Repeat length polymorphism of the serotonin transporter gene influences pulmonary artery pressure in heart failure. Am Heart J 2007; 153: 426-32.

43. Rudski LG, Lai WW, Afilalo J, et al. Guidelines for the echocardiographic assessment of the right heart in adults: a report from the American Society of Echocardiography endorsed by the European Association of Echocardiography, a registered branch of the European Society of Cardiology, and the Canadian Society of Echocardiography. J Am Soc Echocardiogr 2010; 23: 685-713.

44. Lang RM, Badano LP, Mor-Avi V, et al. Recommendations for cardiac chamber quantification by echocardiography in adults: an update from the American Society of Echocardiography and the European Association of Cardiovascular Imaging. Eur Heart J Cardiovasc Imaging 2015; 16: 233-71.

45. Forfia PR, Vachiéry J. Echocardiography in pulmonary arterial hypertension. Am J Cardiol 2012; 110 (suppl): 16S-24S.

46. Bossone E, D’Andrea A, D'Alto M, et al. Echocardiography in pulmonary arterial hypertension: from diagnosis to prognosis. J Am Soc Echocardiogr 2013; 26: 1-14. 
47. Howard LS, Grapsa J, Dawson D, et al. Echocardiographic assessment of pulmonary hypertension: standard operating procedure. Eur Respir Rev 2012; 21: 239-48.

48. McQuillan BM, Picard MH, Leavitt M, Weyman AE. Clinical correlates and reference intervals for pulmonary artery systolic pressure among echocardiographically normal subjects. Circulation 2001; 104: 2797-802.

49. Masuyama T, Kodama K, Kitabatake A, Sato H, Nanto S, Inoue M. Continuous-wave Doppler echocardiographic detection of pulmonary regurgitation and its application to noninvasive estimation of pulmonary artery pressure. Circulation 1986; 74: 484-92.

50. Janda S, Shahidi N, Gin K, Swiston J. Diagnostic accuracy of echocardiography for pulmonary hypertension: a systematic review and meta-analysis. Heart 2011; 97: 612-22.

51. Amsallem M, Sternbach JM, Adigopula S, et al. Addressing the controversy of estimating pulmonary arterial pressure by echocardiography. J Am Soc Echocardiogr 2016; 29: 93-102.

52. D'Alto M, Romeo E, Argiento P, et al. Echocardiographic prediction of pre- versus postcapillary pulmonary hypertension. J Am Soc Echocardiogr 2015; 28: 108-15.

53. Basil A, Liu T, Arkles J, et al. Serial changes in TAPSE correlate with functional assessment and clinical events in patients with PAH. Am J Respir Crit Care Med 2009; 179: A4882.

54. Paczynska M, Sobieraj P, Burzynski L, et al. Tricuspid annulus plane systolic excursion (TAPSE) has superior predictive value compared to right ventricular to left ventricular ratio in normotensive patients with acute pulmonary embolism. Arch Med Sci 2016; 12 1008-14.

55. Sinha N, Devabhaktuni S, Kadambi A, et al. Can echocardiographically estimated pulmonary arterial elastance be a non-invasive predictor of pulmonary vascular resistance? Arch Med Sci 2014; 10: 692-700.

56. Gibbs S. Consensus statement on the management of pulmonary hypertension in clinical practice in the UK and Ireland. Thorax 2008; 63 (Suppl II): 1-41.

57. Fox BD, Shimony A, Langleben D, et al. High prevalence of occult left heart disease in scleroderma-pulmonary hypertension. Eur Respir J 2013; 42: 1083-91.

58. Magne J, Pibarot P, Sengupta PP, Donal E, Rosenhek R, Lancellotti P. Pulmonary hypertension in valvular heart disease. A comprehensive review on pathophysiology to therapy from the HAVEC group. JACC Cardiovasc Imaging 2015; 8: 83-99.

59. Nishimura RA, Otto CM, Bonow RO, et al. 2014 AHA/ACC guideline for the management of patients with valvular heart disease: a report of the American College of Cardiology/American Heart Association Task Force on Practice Guidelines. J Am Coll Cardiol 2014; 63: e57-185.

60. Li M, Déry JP, Dumesnil JG, Boudreault JR, Jobin J, Pibarot P. Usefulness of measuring net atrioventricular compliance by Doppler echocardiography in patients with mitral stenosis. Am J Cardiol 2005; 96: 432-5.

61. Schwammenthal E, Vered Z, Agranat O, Kaplinsky E, Rabinowitz B, Feinberg MS. Impact of atrioventricular compliance on pulmonary artery pressure in mitral stenosis: an exercise echocardiographic study. Circulation 2000; 102: 2378-84.

62. Brochet E, Detaint D, Fondard O, et al. Early hemodynamic changes versus peak values: what is more useful to predict occurrence of dyspnea during stress echocardiography in patients with asymptomatic mitral stenosis? J Am Soc Echocardiogr 2011; 24: 392-8.
63. Kapoor N, Varadarajan P, Pai RG. Echocardiographic predictors of pulmonary hypertension in patients with severe aortic stenosis. Eur J Echocardiogr 2008; 9: 31-3.

64. Faggiano P, Antonini-Canterin F, Ribichini F, et al. Pulmonary artery hypertension in adult patients with symptomatic valvular aortic stenosis. Am J Cardiol 2000; 85: 204-8.

65. Olaf S, Brala D, Ricarda B, et al. Exercise tolerance in asymptomatic patients with moderate-severe valvular heart disease and preserved ejection fraction. Arch Med Sci 2012; 8: 1018-26

66. Magne J, Lancellotti P, Pierard LA. Exercise testing in asymptomatic severe aortic stenosis. JACC Cardiol Imaging 2014; 7: 188-99.

67. Marechaux S, Hachicha Z, Bellouin A, et al. Usefulness of exercise-stress echocardiography for risk stratification of true asymptomatic patients with aortic valve stenosis. Eur Heart J 2010; 31: 1390-7.

68. Lancellotti P, Magne J, Donal E, et al. Determinants and prognostic significance of exercise pulmonary hypertension in asymptomatic severe aortic stenosis. Circulation 2012; 126: 851-9.

69. Magne J, Lancellotti P, Pierard LA. Exercise pulmonary hypertension in asymptomatic degenerative mitral regurgitation. Circulation 2010; 122: 33-41.

70. Magne J, Donal E, Mahjoub $\mathrm{H}$, et al. Impact of exercise pulmonary hypertension on postoperative outcome in primary mitral regurgitation. Heart 2015; 101: 391-6.

71. Heyning CMV, Magne J, Lancellotti P, Pierard LA. The importance of exercise echocardiography for clinical decision making in primary mitral regurgitation. J Cardiovasc Med 2012; 13: 260-5.

72. Lancellotti P, Gerard PL, Pierard LA. Long-term outcome of patients with heart failure and dynamic functional mitral regurgitation. Eur Heart J 2005; 26: 1528-32.

73. Pierard LA, Lancellotti P. The role of ischemic mitral regurgitation in the pathogenesis of acute pulmonary edema. N Engl J Med 2004; 351: 1627-34.

74. McMurray JJV, Adamopoulos S, Anker SD, et al. ESC Guidelines for the diagnosis and treatment of acute and chronic heart failure 2012: the Task Force for the Diagnosis and Treatment of Acute and Chronic Heart Failure 2012 of the European Society of Cardiology. Developed in collaboration with the Heart Failure Association (HFA) of the ESC. Eur Heart J 2012; 33: 1787-847.

75. Guazzi M, Samaja M, Arena R, Vicenzi M, Guazzi MD. Long-term use of sildenafil in the therapeutic management of heart failure. J Am Coll Cardiol 2007; 50: 2136-44.

76. Redfield MM, Chen HH, Borlaug BA, et al. Effect of phosphodiesterase-5 inhibition on exercise capacity and clinical status in heart failure with preserved ejection fraction. JAMA 2013; 309: 1268-77.

77. Loh E, Stamler JS, Hare JM, Loscalzo J, Colucci WS. Cardiovascular effects of inhaled nitric oxide in patients with left ventricular dysfunction. Circulation 1994; 90: 2780-5.

78. Kiowski W, Sutsch G, Hunziker P, et al. Evidence for endothelin-1-mediated vasoconstriction in severe chronic heart failure. Lancet 1995; 346: 732-6.

79. Torre-Amione G, Young JB, Colucci WS, et al. Hemodynamic and clinical effects of tezosentan, an intravenous dual endothelin receptor antagonist, in patients hospitalized for acute decompensated heart failure. J Am Coll Cardiol 2003; 42: 140-7.

80. Louis A, Cleland JGF, Crabbe S, et al. Clinical Trials Update: CAPRICORN, COPERNICUS, MIRACLE, STAF, RITZ-2, RECOVER and RENAISSANCE and cachexia and choles- 
terol in heart failure. Highlights of the Scientific Sessions of the American College of Cardiology, 2001. Eur J Heart Fail 2001; 3: 381-7.

81. Spieker LE, Mitrovic V, Noll G, et al. Acute hemodynamic and neurohumoral effects of selective ET-A receptor blockade in patients with congestive heart failure. J Am Coll Cardiol 2000; 35: 1745-52.

82. Coletta AP, Cleland JGF. Clinical trials update: highlights of the scientific sessions of the XXIII Congress of the European Society of Cardiology-WARIS II, ESCAMI, PAFAC, RITZ-1 and TIME. Eur J Heart Fail 2001; 3: 747-50.

83. O'Connor CM, Gattis WA, Adams KF, et al. Tezosentan in patients with acute heart failure and acute coronary syndromes, results of the randomized intravenous tezosentan study (RITZ-4). J Am Coll Cardiol 2003; 41: $1452-7$.

84. Kaluski E, Kobrin I, Zimlichman R, et al. RITZ-5: Randomized intravenous tezosentan (an endothelin-A/B antagonist) for the treatment of pulmonary edema. A prospective, multicenter, double-blind, placebo-controlled study. J Am Coll Cardiol 2003; 41: 204-10.

85. McMurray JJV, Teerlink JR, Cotter G, et al. Effects of tezosentan on symptoms and clinical outcomes in patients with acute heart failure: the VERITAS randomized controlled trials. JAMA 2007; 298: 2009-19.

86. Packer M, McMurray J, Massie BM, et al. Clinical effects of endothelin receptor antagonism with bosentan in patients with severe chronic heart failure: results of a pilot study. I Card Fail 2005; 11: 12-20.

87. Lewis GD, Shah R, Shahzad K, et al. Sildenafil improves exercise capacity and quality of life in patients with systolic heart failure and secondary pulmonary hypertension. Circulation 2007; 116: 1555-62.

88. Lepore JJ, Maroo A, Bigatello LM, et al. Hemodynamic effects of sildenafil in patients with congestive heart failure and pulmonary hypertension: combined administration with inhaled nitric oxide. Chest 2005; 127 : 1647-53.

89. Califf RM, Adams KF, McKenna WJ, et al. A randomized controlled trial of epoprostenol therapy for severe congestive heart failure: the Flolan international randomized survival trial (FIRST). Am Heart J 1997; 134: 44-54.

90. Guazzi M, Tumminello G, Marco FD, Fiorentini C, Guazzi MD. The effects of phosphodiesterase- 5 inhibition with sildenafil on pulmonary hemodynamics and diffusion capacity, exercise ventilatory efficiency, and oxygen uptake kinetics in chronic heart failure. J Am Coll Cardiol 2004; 44: 2339-48.

91. Stasch JP, Pacher P, Evgenov OV. Soluble guanylate cyclase as an emerging therapeutic target in cardiopulmonary disease. Circulation 2011; 123: 2263-73.

92. Bonderman D, Ghio S, Felix SB, et al.; the Left ventricular systolic dysfunction associated with Pulmonary Hypertension riociguat Trial (LEPHT) study group. Riociguat for patients with pulmonary hypertension due to systolic left ventricular dysfunction: a phase llb double-blind, randomized, placebo controlled, dose-ranging hemodynamic study. Circulation 2013; 128: 502-11.

93. Gurtu V, Michelakis ED. Emerging therapies and future directions in pulmonary arterial hypertension. Can J Cardiol 2015; 31: 489-501. 